Hermann Giliomee

Hermann Giliomee was Professor of Political Studies at the University of Cape Town and is presently Professor Extraordinary at the History Department, University of Stellenbosch. E-mail: giliomee@sun.ac.za

\section{True Confessions, End Papers and the Dakar conference: A review of the political arguments}

\title{
True Confessions, End Papers and the Dakar conference: A review of the political arguments
}

As a social critic Breyten Breytenbach published two books of political commentary and political analysis during the mid-1980s without the opportunity of engaging with commentators at home. While True Confessions of an Albino Terrorist is part autobiography and part searing comment on prison life, End Papers is a more detached dissection of the major political and cultural issues confronting South Africa. Breytenbach was now one of the respected international voices on the political crisis in South Africa. The violent break-up of apartheid had changed Breytenbach's social criticism. In the place of the earlier rejection and denunciation had come a willingness to engage and reason with his audience. The Dakar conference of 1987, which Breytenbach co-organised, offered an ideal opportunity for this. The conference was given wide publicity and was seen by some as the catalyst that broke the ice for the negotiations between the government and the ANC two and a half years later. Key words: Afrikaans literature, Dakar conference, National Party, African National Congress, South Africa, violence, negotiations.

\section{Introduction}

Shortly after being released from jail in 1982 Breyten Breytenbach published two non-fiction books, The True Confessions of an Albino Terrorist (1984) and End Papers (1986). While True Confessions is an emotional and moving account of his prison years, End Papers brings together detached, even clinical commentary on politics, culture and literature during the previous two decades. In 1987 Breytenbach, Frederik van Zyl Slabbert and Alex Boraine organized a conference in Dakar, Senegal between a group of predominantly Afrikaners and a delegation from the African National Congress in exile. Breytenbach participated in the debate and also later, in an exchange of notes with the author of this article, elaborated on his views. The article focuses on Breytenbach's political commentary and analyses between 1984 and 1987.

\section{Confronting fundamental options}

An important part of Breyten Breytenbach's True Confessions of an Albino Terrorist is a dissection of the relationship between him as detainee and his interrogators. The spell in prison intensified his hatred of apartheid, the NP government and the offi- 
cials who interrogated him. Prison became an allegory for apartheid, perverting all human relationships (Sanders 2002: 135).

After Breytenbach's release from jail in 1982 he was more convinced than ever that no significant reform could be expected from the government. "The structure must be shattered by violence [...] The land shall belong to no one. Not even to the deads (sic)" (Breytenbach 1984: 216-7). Apartheid had cut the Afrikaners off from the people in their own country and had led them to betray their identity. "Apartheid is a mutation of power and greed. No religion can justify it, except that warped doctrine the Afrikaners have fashioned from their desert faith. Their god is a cruel, white interrogator" (Breytenbach 1984: 60).

On several occasions Breytenbach refused to call himself an Afrikaner, not to win the favour of his international audience, but because he wanted "his own people to repeat the repudiation; he wants them to become Afrikaners according to a new understanding of the name" (Walzer 1988: 219). He strove for a system in which Afrikaners would enjoy political rights along with other Africans. Replacing a minority dictatorship by a majority dictatorship would be unacceptable. At the same time, however, he rejected constitutional devices or safeguards that would tie down a future black government. As he phrased it, a resolution of South Africa's political crisis would have to occur within a "black socio-cultural field of references" (Breytenbach 1986: 237). Whites would have to learn to trust a black government. As he once playfully phrased it, a white would have to "trust his black nanny to carry him, and to trust her not to drop him" (Galloway 1990: 283; Walzer 1988: 222).

The question was: Could the African Nationalist Congress, as it was constituted in the 1980s, be trusted as a government? On this question Breytenbach remained ambivalent. He wrote: "I have for many years given my allegiance and support to the ANC, which is the political formation representing the majority of Africans" (Breytenbach 1984: 60). However, he was profoundly pessimistic about the possibility of a victorious ANC ushering in a genuine democracy. He pointed out that the South African Communist Party dominated the ANC organizationally, militarily, financially and ideologically. While the ANC stood for the liberation of the African people, the SACP saw the overthrow of apartheid as only a first step, to be followed by a socialist transformation of the kind seen in the Eastern European countries (Breytenbach 1984: 61).

Breytenbach was convinced that it would be the exiles that would dominate the ANC were a swift transfer of power to occur. He thought it unlikely that the ANC would transform itself into a free, democratic organization. The present totalitarian state could be replaced by one that was totalitarian in a different way, "more hegemonic but minus the racism." Breytenbach $(1984: 235,327)$ wrote: "I must warn you the system by which we're trying to replace the present one will grind us down, me and you, inexorably." 
The question is how Breytenbach could contemplate a possibly violent transfer of power only for a white totalitarian state to be replaced by a black one? The short answer is that for him the destruction of apartheid was the first priority. Walzer (1988: 222) sums his main message up well: "He won't paint pretty pictures of a liberal or democratic future [...] the old must be dismantled in any case. There was no other way."

But there are also other reasons for his radical position. In True Confessions he is not only denouncing apartheid and the people executing a pernicious system; he is also lashing out against his enemies, including the ANC and the SACP (Coetzee 2002: 306). His relationship with the ANC leadership was always brittle. In the early 1970s he and a few white radical activists formed a non-communist organization, Okhela that sought to mobilize a small group of mainly white radical activists. It wanted to work not only with ANC cadres inside South Africa, but also with trade union leaders (who were shunned by the Communist-dominated exiled unions at this stage) and Steve Biko, leader of the Black Consciousness Movement. The ANC leadership in exile neither sanctioned Okhela nor did they trust Breytenbach.

When he embarked on a clandestine visit to South Africa in 1975 to promote the aims of Okhela, a senior ANC office-bearer betrayed him to the South African security police. Breytenbach (1993: 123) commented bitterly on being left in the lurch while in jail:

Not only did the ANC withhold assistance from my dependants, not only did they disavow me, but the London clique of bitter exiles intervened to stop any manifestation of international or local support for my cause. They blackballed and maligned me, abetted by well-meaning "old friends" inside the country. Even Amnesty International was prevailed upon not to adopt me as a prisoner of conscience.

Breytenbach never pretended to be a disciplined cadre of any movement or organisation. The ANC-in-exile took and pocketed his denunciation of the regime, but never was prepared to intercede on his behalf.

\section{"A condition of flux"}

When he walked out of jail in 1982, Breytenbach encountered a changed country. In a long analysis written for a French publication in September 1984, he stressed that apartheid could no longer be regarded as unmitigated repression. "All of a sudden", he wrote, "things seem to be in a condition of flux". He warned, however, that the government tightly controlled the policy changes with the aim of containing and even exploiting confrontation. Urban blacks would be given more security and enough political autonomy to justify being grouped as representative entities in a larger confederal set-up. Suffering as a result of diplomatic setbacks, the ANC faced internal upheaval and might be amenable to talks. "All of the above", he concluded, 
"will reinforce the power of those now ruling South Africa, and it will be self-indulgent blindness to pretend otherwise" (Breytenbach 1986: 167-80).

The sudden explosions of black rage in 1960 and 1976 and 1984, each followed by floundering efforts on the part of the state to restore order, prompted many commentators to revise radically their assessment of the capacity of government to respond effectively to a mass uprising. The spectre of a protracted civil war concentrated their minds. Instead of emphasizing the power of government, they now tended to dismiss the possibility of the white government resuming the initiative or offering a platform for negotiations. The same would happen after September 1984 when a violent uprising broke out on the Witwatersrand that soon spread to most parts of the country. Breytenbach's assessment of the stability of the system changed markedly.

In April 1985, with 250 people killed in the violent protests that had erupted nine months earlier, Breytenbach (1985; 1986: 198-9) wrote an article that appeared in abridged form in the Los Angeles Times and International Herald Tribune. He concluded that the nature of the conflict had changed substantially. Despite the revolt, whites refused to compromise on what they saw as the core condition of their survival: a "white minority power monopoly"; on this they would brook no negotiation. But blacks were no longer pleading for participation. "The white state is rejected [...] The civil war in South Africa has started" (Breytenbach 1986: 198-9).

In a paper delivered early in 1985 on the ethics of resistance, he stated unambiguously that the state had to carry the responsibility for the violence that was threatening to spill out of control. The state was unique in its introduction of massive state violence against its citizens, "It has the capacity to wreak havoc in Africa" (Breytenbach 1986: 188).

In 1986 Breytenbach returned to South Africa for a first visit after his release from jail. Accepting the Rapport Prize he warned of the danger where apartheid could only be "smothered in blood" (Rapport, 13 April 1986). However, where he earlier tended to dismiss any possibility of significant change emanating from the Afrikaner intelligentsia he now challenged them to take their future in their own hands: Whites could still avert a revolution and the Afrikaners could still break out of their isolation (Galloway 1990: 236-8). In addressing students in Stellenbosch, Breytenbach pointed out that it was not necessary to renounce their "Afrikanerskap" to become South Africans. They could claim their place in a future order if they participated in a struggle the aim of which was to undermine and subvert the place they now occupy. However, failure to participate in the struggle would weaken Afrikaners' claims in a post-apartheid order (Breytenbach 1986: 12).

He was now no longer the angry prophet, excoriating his people, but a valued interlocutor, appealing to their better instincts. Among the Afrikaners the profound ambivalence towards Breytenbach deepened. Even in jail he was never cast out. As Coetzee (1992: 377-8) remarks: “The terrorist in Breytenbach could be incarcerated 
and punished, while the poet in him could be left free." It was the unique way in which he expressed a feel for the land, and a love for the language that gripped the attention (Coetzee 2001: 314). For successive generations of Afrikaner students he remained a charismatic figure, projecting idealism and integrity.

\section{Organising the Dakar conference}

While Breytenbach was in jail Van Zyl Slabbert, as leader of the official opposition in Parliament, tried on several occasions to persuade State President Botha to release him earlier. After his release a close friendship developed between them, although their views still differed. As late as November 1985 Slabbert had not yet given up on the government initiating a movement towards substantial change. In a private interview with Botha he said that the idea of an all-powerful ANC was a myth. Botha "could pull the teeth of the whole ANC story." It was, in Slabbert's words, "not on" for the ANC leadership to insist that the government must "negotiate the transfer of power out of [their] own hands to whatever majority." He also agreed with Botha that a white person had a right to maintain "his cultural rights, his way of life, his language", and "to have his children educated in his own way". He pointed out that there were few, if any, historical precedents for the peaceful transfer of power from a minority to a majority. Black liberation was impossible without white security (South Africa Digest, 1986).

Botha failed to discern the intention of Slabbert's initiative, which was an attempt to get government's backing for an idea of a convention in which the major black and white leaders would seek a compromise. The President made the far-fetched claim that more than half of the black population supported him and were satisfied with the rights the apartheid system had yielded to them. This frustrating interview with Botha prompted Slabbert to make an abrupt change of course: from a loyal critic, using Parliament as his base, to a critical ally of the liberation movement. Early in 1986 he resigned from Parliament, calling the institution irrelevant.

Slabbert thought that a civil war could be averted through starting talks with the ANC. In 1985 Thabo Mbeki had told him and other members of his party's executive that the armed struggle was the only way forward for the ANC. Privately, however, he said to Slabbert that "talking is better than killing" and that negotiations could be explored (Slabbert 2006: 46). With increasing urgency, Slabbert spread the message to voters that no resolution of the country's crisis was possible without the ANC.

Shortly after leaving Parliament Slabbert and Alex Boraine, a PFP member of Parliament who had resigned with him, founded the Institute for a Democratic Alternative for South Africa (IDASA). At a meeting in New York shortly afterwards Slabbert met Thabo Mbeki. He told him not to underestimate the importance of growing numbers of Afrikaners, particularly academics, who had broken with Afrikaner na- 
tionalism and apartheid. Here the idea emerged of a meeting between a group of mainly Afrikaans-speaking South Africans and some leading members of the ANC (Leach 1989: 149).

A few months later Slabbert and Breytenbach met on the island of Gorée off the coast of Dakar, Senegal. They decided that Dakar was a suitable venue. Slabbert and Boraine raised the funds in United States, and found George Soros, a well-known international financier, willing to donate a substantial sum, although he feared that South Africa was doomed and the conference futile. In the mean time Breytenbach used his contacts with Danielle Mitterand, the French president's wife and head of the France Liberté institute, to smooth the entry into Senegal. She enjoyed a good relationship with Abdou Diouf, the Senegalese President.

On 3 June 1987, just more than a year after the proclamation by the South African government of a national state of emergency, the press broke the news of an imminent meeting in Dakar between an ANC delegation of 11 senior members (more than half went on to become cabinet members), led by Thabo Mbeki, and a group of 59 people invited by IDASA. Breytenbach stated that his love for the land and its people prompted him to help organize the meeting. "As long as people talk, there is no time for shooting" (Galloway 1990: 261). The IDASA group consisted of approximately sixty people personally invited by Slabbert or Boraine and did not represent any institution. Half were white Afrikaans-speaking academics, teachers, journalists, artists, directors, writers and professionals. The group also included several coloured Afrikaans speakers ten English-speaking businessmen and academics and three German political scientists working on South Africa.

The only known record of the Dakar conference, held from 9 to 12 July, is an ANC document of 80 pages, written by Tony Trew and some anonymous ANC members (ANC 1987). A few members of the IDASA group published their impressions in the journals Die Suid-Afrikaan and Frontline and in newspapers. There is also a film of the Dakar meeting, produced by Kathy Boraine and Hennie Serfontein.

During the conference Breytenbach and Slabbert rarely spoke, apart from press briefings. Their views were well known and it is also possible that, as the organizers, they did not want to play too prominent a role. As could be expected, the topic of violence dominated the discussion. Other topics included the quest for a democratic alternative, the ANC's commitment to an equitable non-racial future, economic policy in a post-apartheid society, and cultural and language rights, with a particular emphasis on the future position of Afrikaans.

\section{Violence and a negotiated settlement}

As the ANC conference account makes clear, its delegation was imbued with the notion that on all issues, including that of violence, the organisation occupied the 
moral high ground. The organisation had been in the vanguard of a long peaceful battle for rights and liberty against apartheid. It had turned to violence in the early 1960s, but only when its non-violent protests fell on deaf ears. The ANC delegates stated that the organisation in principle refused to engage in mass violence and, if civilians died, it was unintentional. It was committed to observing the Geneva protocols and its guiding principle of the "proportionality of means" (ANC 1987: 67-9).

The ANC delegates took a deterministic view of the struggle. They believed their organisation had seized the strategic advantage and that "victory was certain". It envisaged negotiations at a "two-sided table" as an imminent prospect. On the one side would be the representatives of the state and all other "racist" forces (which would include Inkatha and other "reactionary" organisations) and, on the other side, the forces for liberation and popular democracy under the ANC's leadership. Among the latter would be representatives of trade unions, churches and selected "progressive [white] liberals" (ANC 1987: 67-8).

André du Toit (1987) gave the keynote speech on the subject of violence. To him the state's violence and the ANC's armed struggle had both become historical realities. He took issue with the notion of two clearly defined sides waging a battle, preferring instead to speak of a proliferation of internecine conflicts, and warning that indiscriminate violence and terror on the part of the insurgents could damage the political cause of resistance. He warned the ANC: "Revolution is not around the corner - the heady assessments of recent years are gone." The state would never win legitimacy by using large-scale coercion, but there were also distinct limits to the ANC challenge to state power (ANC 1987: 6-7). In the Dakar declaration, endorsed by all participants, deep concern was expressed about the proliferation of uncontrolled violence (Slabbert 2006: 76).

The conference's emphasis on uncontrolled violence was misplaced. Reports would later indicate that most of the violence was coming from the two major contenders for power, the government and the ANC. The government was intent on using force to eliminate the ANC as a factor, and although the cabinet tried to avert its gaze, state agencies deliberately targeted ANC activists to "eliminate" or "remove" them from society. While both the ANC and its internal ally, the United Democratic Front, lacked the capacity to control what was happening on the ground, their general strategy was to use violence against black policemen, councillors or informers, described as agents or collaborators, and against political opponents interested in negotiating with the government, particularly Inkatha. (Coloured and Indian "collaborators" were not targeted at all). Violence was the ANC's veto against any black effort to bypass it. The IDASA group ignored the possibility that the ANC was violently trying to establish its hegemony over black South Africans (Jeffery 2009: forthcoming).

The prospects for a negotiated settlement were next on the agenda. All the conference participants endorsed such a settlement. The government's demand that the 
ANC first had to foreswear violence was generally seen as the main obstacle in this regard. Thabo Mbeki explained that accepting this demand would put the ANC in a no-win situation: "It is too easy for one's opponents to set off bombs exactly to demonstrate that you are not in control of your forces" (Leach 1989: 156). The political stalemate could be unlocked by the unconditional release of Nelson Mandela. "The cessation of conflict is not and has never been a necessary condition for negotiations to take place" (ANC 1987: 13).

While this was true, it evaded some issues. Escalating violence also had a dynamic of its own and could fatally damage the prospects for a negotiated settlement. As Slabbert pointed out, "the strategy of armed struggle had direct consequences for other democratic strategies" (ANC 1987: 16). Bombs going off could stifle a willingness to talk. At the end of the conference the participants unanimously endorsed the goal of a negotiated settlement leading to a non-racial democracy. They generally saw the government's insistence that the ANC should unilaterally foreswear violence as the main obstacle to such negotiations.

What were the prospects for a negotiated political settlement, if the issue of suspending violence could be overcome? One of the major problems was that no one at the conference really knew how much support the ANC actually enjoyed. Opinion polls commissioned by government in the second half of the 1980s showed consistently that ANC attracted the support of more than 85 percent of blacks (and more than 60 percent of electorate), while the NP managed to muster the support of some 20 percent of blacks (Steward 2008). For fear of scaring its supporters, the government did not publish these polls.

Lawrence Schlemmer, an academic in the IDASA delegation with long polling experience, stated in an address to the conference that the ANC enjoyed majority support among the population. It could thus afford electoral competition. Arguing that national unity was only possible within diversity, he urged the movement to accept decentralised power, regionalism and federalism.

Pallo Jordan, ANC head of research, rejected any form of decentralised power. There had to be unity and "unity could only be demonstrated through unity in action." He argued that all groups existing in South Africa had been "created, sustained and nurtured by state policy. The cleavages can be unmade precisely because they were manufactured [by apartheid]". The emergence of a new nation had to be based on a rejection of the divisions on which apartheid was based. He warned that the future government would impose a policy of "liberatory intolerance" towards organisations based on race or ethnicity (ANC 1987: 18-9, 70). This was an ideological interpretation as sweeping as apartheid.

The other ANC delegates were also not prepared to make any significant concessions to minorities. They did not think a Bill of Rights was necessary to assuage their fears and were of the view that the Freedom Charter offered enough guarantees for 
them. They also dismissed pleas for power-sharing, federalism or the decentralisation of power. They claimed that any of these mechanisms to curb the power of the majority could serve to buttress existing privilege. The ANC had begun only two years before to admit members of racial minorities to its executive. Nevertheless, some of the IDASA delegates insisted that the ANC's record of fighting against racial exclusivists, such as the Pan African Congress, spoke for itself.

Dominating the discussion was the assumption that the ANC's commitment to non-racialism made minority or group rights superfluous. The debate reminded one of a comment by Staniland (1986: 70): "Nationalism could speak unto nationalism; liberalism often seems just to be talking to itself." Not only the ANC delegates but also some of the members of the IDASA group insisted that the ANC, far from being a nationalist movement, was genuinely non-racial, even liberal in character. Hanf (1989: 108-9), a German political scientist who attended the conference, later expressed a view that was quite common at the conference: ANC thinking reflected not so much nationalism per se as "the universalism of Christian as well as Marxist thought [...] rooted in the concept of the brotherhood of all men." All South Africans "were brothers in the eyes of the ANC", which desired "equality and fraternity" and "rejected all forms of group thinking." The "power of this non-racial ethic" was "extraordinary" and "heroic". It was for this reason "that any form of communalism was anathema to them."

The ANC's plea that its commitment to a non-racial democracy without minority safeguards be accepted was ultimately based on a moral argument. Ranking apartheid with the evils of the slave trade and the Holocaust as an ultimate crime against humanity, it depicted the ANC's struggle as one that would liberate not only blacks but whites as well. Guarantees to minorities would demean the liberation struggle and the freedom that it would bring for all.

In his writings before the conference Breytenbach at times tried to assuage fears of white marginalisation in a future political order by arguing that black society was comprised of different political groups, which ruled out "a unitary black majority." Whites should not be afraid of majority rule. Negotiations could prevent the tyranny of an absolute majority and the marginalisation of minorities (Galloway 1990: 283; Walzer 1988: 222).

But the question was: what would happen if the ANC won with an overwhelming majority in the first election, making it unnecessary to form a coalition government? Some scholars working in the field strongly warned against the disastrous consequences of untrammelled majority rule operating under the guise of a liberal democracy. They pointed out that the latter system worked only in a homogenous society, where political beliefs and material interests rather than racial identity determined the voters" choices. Kedourie (1987: 1) warned that the "worst effects of the tyranny of the majority are seen when the tyranny of the majority is introduced in countries divided by religion or language or race." 
These scholars suggested an alternative form of democracy, called consociationalism or power-sharing between groups, always on the condition that the groups should not be defined and imposed by government (as in apartheid) but voluntarily formed. In a book entitled Political Domination in Africa, Sklar (1986: 25) warned that democratic movements that disregarded consociational precepts "did so at their own peril." However, the ANC delegates scoffed at this model, preferring instead what they called an "ordinary democracy."

In the discussion on a post-apartheid economy, Leon Louw, an office-bearer of the Free Market Foundation, entered a plea for massive decentralisation and privatisation, to which the ANC delegates replied with a strong insistence on state intervention to "democratise" the economy. Some expressed the view that the system ultimately had to culminate in socialism. Appealing to the Freedom Charter, they demanded the nationalisation of the mining and banking sectors, the redistribution of the land and collectivised agriculture. The new South Africa would have to guarantee "the masses of the people freedom from hunger, disease, ignorance, homelessness and poverty." Schlemmer warned that all-or-nothing strategies could actually strengthen the regime (ANC 1987: 26-34,75). The few businessmen who attended the Dakar conference took home the ANC's radical criticism of the economic policy. The business community in South Africa would soon embark on initiatives to win the movement over to market-oriented policies.

The IDASA delegates were silent about the fact that Communism and Communist activists exercised an extraordinary influence on the ANC in exile. Breytenbach was the only participant who expressed a word of caution. Referring to Communism, he said that "in supporting the struggle we are supporting a move towards a system which we have seen in neighbouring countries not to be successful" (ANC 1987: 11). He had pulled no punches in his True Confessions about the extraordinary strategic leverage of Communists in the movement. At the conference none of the internal South Africans quoted Breytenbach's view. Tending to dismiss the propaganda of the South African government too readily, they missed the opportunity to delve deeper into an important issue.

Remarkably the conference did not discuss the rapid decline of democracy in Africa and the steady deterioration in state capacity in independent African states by the 1980s. All-powerful dominant parties strutted the stage and tolerated little opposition. They rigged elections, emasculated the courts, cowed the press and stifled the universities. Leaders made themselves exceedingly rich (Meredith 2005: 379). There was a tendency at the Dakar conference to assume that the ANC was too smart to fall into this trap. As Du Pisani, an Afrikaner political scientist, remarked in his notes: "The organisation draws upon all the most recent developments in international law" (ANC 1987: 72). 


\section{The position of Afrikaans}

In his account Boraine (2008: 154) noted: "Hermann Giliomee, Lawrie Schlemmer and others kept raising the issue of the future of the Afrikaans language." In his view Pallo Jordan put these people in their place when he replied in fluent Afrikaans that they should not worry only about Afrikaans but about Xhosa and Zulu as well. Jordan said something along the same lines: "The future of Afrikaans is assured - if for no other reason than that it is the language of many black people" (ANC 1987: 26). Boraine continued: "They had not been reassured about the position of Afrikaans in a democratic society; indeed to this day Giliomee remains obsessed with Afrikaners and their language."

African nationalist movements in other parts of Africa wasted no time in elevating the colonial language to the position of the only effective public language, but the conference took no note of this. The ANC delegates would not concede that a minority language enjoyed a legitimate claim to enforceable language rights. Du Pisani described their stance: "The ANC is prepared to give assurances on cultural rights to Afrikaners." Paraphrasing the common view expressed by ANC delegates (but using an exclamation mark to distance himself), he stated: "The best assurance for the continued existence for Afrikaans is the fact that the ANC cadres talk Afrikaans!" (ANC, 1987: 72). Few members of the IDASA group questioned the ANC assurances that it would not marginalize minorities. There was no reference to other countries in Africa where nationalist movements, soon after coming to power, ruthlessly displaced members of minorities from civil service jobs or expelled them from the country in the name of Africanisation. Schlemmer (2001: 179) later described the mutation of the ANC's non-racialism. "It starts off from the position of non-racism and it then qualifies this with a commitment to closing racial gaps in order to achieve a legitimate basis for non-racialism, and from there it proposes a range of race-based affirmative action and empowerment policies to give effect to this."

The ANC delegates gave little indication of how they thought that the ANC could impose its ideas about democracy and socialism. It was pointed out to them that the state had succeeded to a large extent in re-imposing its authority by using emergency powers. A member of the internal group recorded his sense of bafflement.

Listening to the ANC was like reading Revelations 21. They had an apocalyptic vision of a great moment of Change, where all democratic forces would be on the one side of the negotiating table under the leadership of the ANC, with the government on the other side, working out the hand-over of power. It was not even a round-table concept, but a two-sided table. (Kriel 1987: 23)

In this context I posed the question: if there was only a scant prospect of the ANC toppling the state, was it not advisable to seek a compromise solution? I argued as follows: 
The conflict is not between democracy and racism, but between Afrikaner and African nationalism. There is a need to fuse the two. The way forward is bi-communalism. Non-racialism cannot be established by the elimination of Afrikaner nationalism. There are fears that the Afrikaner minority will be in the position of the Jews under Nazism. (ANC 1987: 23) ${ }^{1}$

I accepted that Afrikaner and African nationalism were quite different in nature African nationalism was territorially based, tolerant and integrative, while Afrikaner nationalism, based on ethnicity, tended to reify differences in descent and culture in order to prevent a common nation being forged - but the fact was that neither could prevail over the other and neither could exploit the full potential of South Africa without the other. In this context I cited Van Wyk Louw's words about the tragic situation in which the respective "rights" of two nations stood implacably opposed to each other and in which a solution that allowed the one to triumph over the other itself became unjust.

I argued that, if this was accepted, both Afrikaner and African nationalism had to be accorded some legitimacy. Negotiations and a future government would be based mainly on a coalition of the two "nations", "blocs" or "groups" (Giliomee and Schlemmer 1989). I had failed to recognise that Afrikaner nationalism had steadily become eroded during the 1980s and was at war with itself. The National Party could win only half the Afrikaner vote in the 1992 referendum and would disintegrate over the next ten years.

My comments sparked a heated response, with Jordan in particular strongly rejecting the view. Breytenbach also disputed the view that a parallel could be drawn between "the exclusivist ideology of Afrikaner nationalism and the integrative movement for national liberation" (ANC 1987: 23). In written comments he and I exchanged just after the conference, he deplored any attempt to depict the ANC as a nationalist movement that used non-racialism as an opportunistic tactic to attract allies from outside the black community.

In these notes, which were later published, Breytenbach (1988: 23-4) expressed himself as follows.

It is not true that the ANC only "pretends" to be non-racist while its driving force actually is a black nationalism. [...] We have no right to suspect them of operating under false pretences. [...] It was to be tragically blind to talk of a struggle between two nationalisms [...] I don't think that the road to nation-building goes through any form of entrenchment of "group rights" or "blocs". Those "flowers" are lethal (doodsblomme). At the very least it attempts to take apartheid out of the cancer in order to retain the cancer. ${ }^{2}$ 
Commenting on the exchange, Pallo Jordan (1988: 24, 29) extolled the ANC non-racial tradition that "had been drilled into the average ANC member so that it was almost second nature." He dismissed Van Wyk Louw's notion of Afrikaner and African "rights" that stood implacably opposed to each other. Such views granted to Afrikaner nationalism an "unwarranted legitimacy to a political doctrine that is radically evil" (italics in the original). He added that Van Wyk Louw's liberal credentials notwithstanding, on this score he was "an abject apologist for tyranny and oppression." In a future South Africa the Afrikaners, like minorities elsewhere, had to rely on democratic institutions and practices to protect them against discrimination and oppression. Jordan's view foreshadowed that of the ANC in the negotiations that started in 1990 and its implementation of a policy of transformation. It appealed simply to "a non-racial democracy", but used policy to make structures in all walks of life "racially representative", "representative of the population composition". While using democratic language, the ANC in fact practised what Taylor (1998: 148) called a form of "democratic exclusion" that recognises a single political identity and imperiously excludes other identities. In his introduction to a book The Liberal Dilemma in South Africa, Van den Berghe (1979: 7) puts the issue well:

If your constituency has the good fortune to contain a demographic majority, racism can easily be disguised as democracy. The ideological sleight of hand, of course, is that an ascriptive racially-defined majority is a far cry from a majority made up of shifting coalition on the basis of a commonality of beliefs and interests. "Majority rule" in Africa can thus easily become a veneer for racial domination.

The Dakar conference demonstrated in potent symbolic terms that the ANC had become part of the main stream of the debate and the government could no longer silence it. For the English press (with the notable exception of The Citizen) the Dakargangers engaged in a potent act of dissent. The Afrikaans press, and Die Burger in particular, denounced the conference, arguing that it was an attempt by Slabbert to embarrass the government, expose Parliament's lack of legitimacy and boost the ANC as an extra-parliamentary movement.

As Louw (1987) points out, the extraordinary efforts on the part of the Afrikaans press to denounce the conference contained an implicit acknowledgement that negotiations between the government and the ANC were indeed on the agenda. The problem was that the government had become bogged down by indecision. All the Afrikaans press could do was to discredit the IDASA group as useful idiots. In Parliament members of the Conservative Party pointed out that several university lecturers, who were state employees, were among the participants in the conference. Although the ANC was a banned organisation, the state took no action against these lecturers who, on their return, openly discussed the ANC's policy objectives and strategies (Debatte van die Parlement 17, 1987 cols 2469-70, 2514). 


\section{Conclusion}

In his essay on Breytenbach as a part of his study on the major social critics of the twentieth century Walzer (1988: 211) noted that "poetry is probably easier than social criticism, for the poet listens with his inner ear, while the critic depends on an actual dialogue." Except for his brief 1973 visit, Breytenbach's exposure to other social critics was limited. True Confessions recounts his "dialogue" with interrogators and fellow prisoners under harrowing conditions. End Papers, written in exile, was an attempt far from the scene to make sense of the first signs of apartheid breaking up.

The Dakar conference for the first time subjected Breytenbach, like all the other participants, to wide-ranging debates and dialogue with white and black South Africans over the country's future. Like Slabbert, he played the role of interlocutor encouraging dialogue, believing in what J. M. Coetzee called "the potential for a complete turnaround in the history of South Africa" (cited by Truehart 1990). However, when Breytenbach returned to South Africa in 1991 such a hope was quickly dispelled. He would write bitterly of the ANC's betrayal of the revolution. He had not fought for a new hegemony with "the same mechanisms, the same sadness" (Breytenbach 1993: 215). But, then, he had always stressed that, as a poet, he spoke only for himself and "with the right to imagine a future beyond the dreams of politicians."

Notes

1. I cited the words of Van Wyk Louw (1986: 505) to the effect that, "if the Afrikaners became a minority, they would be as helpless as the Jews were in Nazi Germany." Some commentators took this to refer to the Holocaust, but Louw was undoubtedly referring to the quota system for jobs and admission to universities that was imposed on Jews.

2. "[D]is eenvoudig net nie waar om te beweer dat die ANC hom as nie-rassig 'voorstel' terwyl die eintlike dryfkrag dan swart nasionalisme sou wees nie [...] Ons het geen reg om hulle te verdink van [...] valse voorkomste nie. [...] Om dit te tipeer as ' $n$ konfrontasie tussen 'twee strydende nasionalismes' is om van wit kant ' $n$ tragiese blindheid aan die dag te lê. [...] Ek glo nie ons pad na nasiebou loop deur enige vorm van verskansing van 'groepsregte' of 'blokke' nie. Dis doodsblomme daai. Op sy allerminste: Apartheid uit die kanker haal om die kanker te kan behou."

Works cited

African National Congress. 1987. Paris-Dakar meeting. Cape Town: Mayibuye Centre, University of the Western Cape. Unpublished manuscript.

Boraine, Alex. 2008. A Life in Transition. Cape Town: Zebra.

Breytenbach, Breyten. 1984. The True Confessions of an Albino Terrorist. Johannesburg: Taurus. 1985. The civil war in South Africa has started. International Herald Tribune, 27 May. 1986a. End Papers. London: Faber \& Faber.

1986b. Die game is nog lank nie verby nie. Die Suid-Afrikaan, 6: 10-2. 1988. Denke nog nie los uit die wit verf nie. Die Suid-Afrikaan, 13: 23-5. 1993. Return to Paradise. London: Faber \& Faber.

Coetzee, J. M. 1992. Doubling the Point. Cambridge: Harvard University Press. 2001. Stranger Shores: Essays, 1986-1999. London: Vintage Books.

Debatte van die Parlement, 17. 1989.

Du Toit, André. 1987. Beginning the debate. Die Suid-Afrikaan, 11: 18-20. 
Galloway, Francis. 1990. Breyten Breytenbach as openbare figuur. Pretoria: HAUM.

Giliomee, Hermann. 1988. Nasionalisme kan nie ontken word nie. Die Suid-Afrikaan, 13.

and Lawrence Schlemmer. 1989. From Apartheid to Nation-building. Cape Town: Oxford University Press.

Hanf, Theo 1989. The prospects of accommodation in communal conflicts. In Hermann Giliomee \& Lawrence Schlemmer (eds.). Negotiating South Africa's future. New York: St. Martin's Press.

Jeffery, Anthea. Forthcoming. People's War: New Light on the Struggle for South Africa. Johannesburg: SA Institute of Race Relations.

Jordan, P. 1988. Why won't Afrikaners rely on democracy? Die Suid-Afrikaan, 13: 24-5.

Kedourie, Eli. 1987. One-man-one-vote, South Africa International, 18 (7): 1-7.

Kriel, Jacques. 1987. The human face of Dakar. Frontline, July.

Leach, Graham. 1989. The Afrikaners: Their Last Great Trek. London: Macmillan.

Louw, Chris. 1987. SA pers oopgevlek. Die Suid-Afrikaan, 11.

Louw, N. P. van Wyk. 1986 Versamelde Prosa, 1. Cape Town: Tafelberg.

Meredith, Martin. 2005. The State of Africa: A History of Fifty Years of Independence London: Free Press.

Sanders, Mark. 2002. Complicities: The Intellectual and Apartheid. Durham: Duke University Press.

Sklar, Richard. 1986. Democracy in Africa. In Patrick Chabal (ed.). Political Domination in Africa. Cambridge: Cambridge University Press.

South African Digest. 1986. The Full Transcript, 28 February.

Slabbert, F. van Zyl. 2006. The Other Side of History. Johannesburg: Jonathan Ball.

Staniland, M. 1986. Democracy and ethno-centrism. In Patrick Chabal (ed.). Political Domination in Africa. Cambridge: Cambridge University Press.

Steward, D. 2008. Interview with author, 23 May.

Taylor, Charles. 1998. The dynamics of democratic exclusion. Journal of Democracy, 9 (4).

Truehart, C. 1990. J. M. Coetzee: Voices of Afrikaner conscience. International Herald Tribune, 28 November.

Van den Berghe, Pierre. 1979. Introduction. In P. Van den Berghe (ed.). The Liberal Dilemma in South Africa. New York, St. Martin's Press, 143-56.

Walzer, M. 1988. The Company of Critics: Social Criticism and Political Commitment in the Twentieth Century. New York: Basic Books. 